\title{
Pricing in The Case of Privately-Owned Water Utilities
}

Dr. Martin Williams, Economics, Northern Illinois University

\begin{abstract}
This paper is concerned with the extent of price discrimination among customer classes for privately-owned water utilities that are regulated by state commissions. The test of price discrimination requires the specification and estimation of long-run marginal cost functions for each class of customer and prices of service. This procedure yields the price-long-run marginal cost ratios for each customer class required to test for price discrimination. We examine whether the rates afforded the respective customer classes are set in accordance with variations in the elasticity of demand of the respective customer classes. In so doing, we proceed to test the existence of Ramsey pricing.
\end{abstract}

\section{Introduction}

Privately-owned systems comprise only fifteen percent of the water utility industry (Farris and Sampson, 1973). Public ownership dominates the industry. But public ownership of water utilities, like any other public ownership has been debated on both ideological and economic grounds. The debate among economists has centered mainly on efficiency in resource allocation and use. Economists have long recognized that in most circumstances in most industries, private enterprise has been more efficient than public enterprise (Meyer, 1975).

With respect to the pricing policies in the water industry, the traditional approach has been to set prices equal to the average cost of supplying water-that is, the water utility attempts to break even. Of course, the definition of costs is assumed to be such that the water utility should obtain adequate gross revenues to provide service and maintain equipment (Hanke, 1976). Little consideration has been given to the marginal cost of supplying water or to the view of imposing a scarcity rent similar in nature to a Hotelling (1931) rent where water supplies are depleted (Williams and Suh, 1986).

Although the price-equals marginal cost debate has centered mainly around the question of time of year pricing schemes, there has also been interest in developing distance based pricing policies for water. In any case, Hanke (1981), in examining the performance of publicly-owned systems found that they tend to charge rates below cost thus making it difficult for them to generate enough revenue to upgrade and maintain equipment. In this regard, Hanke suggests the possibility of substituting private control of public systems in order to attract enough capital to upgrade plant and equipment and improve their efficiency. But before we lend support to the advocates of private control of public systems it is important to shed some light on the pricing policies of privately-owned systems. Whether or not the privately-owned segment of the water industry offer favorable rates to particular customer groups and under what conditions are empirical questions which up to the present have been neglected. This gap in the literature must be filled.

In effect, this is precisely what we propose to do in this paper. In section 2 , we review briefly the relevant arguments from the public utility literature on rate regulation and price discrimination among customer classes. In section 3 , we develop empirical tests of price discrimination for privately-owned water systems. In section 4, we test for the existence of Ramsey pricing in this industry. Finally, section 5 offers some concluding remarks.

\section{Rate Structure under Regulation}

Rate regulation at the state and local level is pervasive in the water industry. Publicly-owned systems are controlled and regulated by state commissions, city councils, local water commissions, and specially-elected boards (Keig, 1970). Privately-owned systems are regulated exclusively by state commissions. Numerous studies on utilities in general conclude that regulators serve the private interest of the regulated industry rather than the public interest (Keeler, 1972; Peltzman, 1976). The public interest theory asserts that regulation corrects market imperfections (due to monopoly power) or deviations between social and private costs. The political-economic theory asserts that this lofty goal is often 
compromised, and as a result, regulatory behavior benefits the regulated industry (Stigler, 1971).

Recently, Stigler (1971) and Peltzman (1976) provide a more general theoretical framework of regulation that treats the public interest theory and capture theory as limiting cases. They maintain that regulation serves the private interests of more supportive political constituents. Accordingly, the regulatory process selectively rewards and hurts certain interest groups (Peltzman, 1976). Indeed, maintaining political support may be the overriding concern of regulators in offering favorable rates to special customer groups (1). DeAlessi (1974) suggests that the commercial and industrial customer classes tend to be the favored classes since they can exercise significant economic and political powers to affect the desired regulatory outcome. While Stigler and Friedland (1962) suggest that regulators who favor the larger number of residential users are also motivated and influenced by the political considerations. Ultimately, which customer class is the chief beneficiary of regulation is an empirical question.

Price discrimination occurs when customers are charged different prices for essentially the same product or service and the difference cannot be accounted for by the variation in cost of providing the product or service. Significant price discrimination is feasible for the firm with market power, differing sensitivity to price changes among user groups (price elasticities of demand), and if the seller has the ability to separate different customer classes (residential, commercial, industrial) so that the resale of the product or service is prohibited. The resale of utility services such as electricity and water which require physical connections between the facilities of producers and customers, is extremely difficult and this provides for successful price discrimination.

State regulatory agencies are charged with the responsibility of formulating and regulating prices for privatelyowned water systems. The provision of water service is characterized by economies of scale (Kitchen, 1977). Regulators may require the utility to set prices equal to marginal cost. With increasing returns to scale, marginal costs are less than average costs. Thus, pricing at marginal cost may cause the utility to incur revenue deficits. These losses must be financed if the utility is to continue to deliver service. Ramsey pricing is an adequate mechanism for designing rate structures to cover such losses; it is commonly called the inverse elasticity rule.(2)

\section{Estimation Procedure}

In this section we discuss the basic procedure used to test for the existence and direction of price discrimination in the rate structures of investor-owned water utilities that serve the residential, commercial and industrial customer classes.

We estimate short-run and long-run marginal cost functions for water utilities in the sample. We derive long-run marginal cost estimates for each customer class as the sum of the short-run marginal costs and the incremental costs of expanding existing capacity to meet future demand. The statistical procedure used was ordinary least squares regression analysis and the specific equations tested are discussed in what follows.

The marginal cost of producing water can be estimated from the total variable cost function as represented in equation [1].(3)

$$
\mathrm{TVC}=\alpha_{\mathrm{o}}+\alpha_{1} \mathrm{Q}_{\mathrm{w}}^{2}+\alpha_{3} \mathrm{CP}+\alpha_{4} \mathrm{CP}^{*} \mathrm{Q}_{\mathrm{w}}+\mathrm{e}
$$

where

TVC = annual operating, administrative and maintenance and repair costs $(\$ 1,000)$

$\mathrm{Q}_{\mathrm{w}}=$ quantity of water produced in the system (million gallons, annually)

$\mathrm{CP}=$ capacity of the water system (defined as the 24hour peak demand times 365; expressed in million gallons)

$\mathrm{e}=$ error term

The plant capacity variable (CP) which is measured in million gallons of water achievable annually from the system is a proxy for plant size. To obtain an estimate of the short-run marginal cost (SRMC) of providing a unit of water, we partially differentiate equation [1] with respect to quantity. Thus,

$\mathrm{SMRC}=\alpha_{1}+2 \alpha_{2} \mathrm{Q}_{\mathrm{w}}+\alpha_{4} \mathrm{CP}$

A water utility loses water in the distribution process. Because of distribution losses, more than one gallon of water has to be delivered to provide one gallon to the customer class (e.g., residential, commercial, industrial). Distribution loss was estimated by the following equation specification:

$D L=d_{o}+d_{1} Q_{r}+d_{2} Q_{c}+d_{3} Q_{i}+d_{4} Q_{o}+d_{5} M+e$

where

$\mathrm{DL}=$ quantity of water lost in the distribution system (in million gallons, annually)

$\mathrm{Q}_{\mathrm{r}}=$ quantity of water consumer by the residential customer class (million gallons annually)

$\mathrm{Q}_{\mathrm{c}}=$ quantity of water consumer by the commercial customer class (million gallons annually)

$\mathrm{Q}_{\mathrm{i}}=$ quantity of water consumer by the industrial customer class (million gallons, annually)

$\mathrm{Q}_{\mathrm{o}}=$ quantity of water consumer by supplementary customers (e.g., public and wholesale, in million gallons) 
$\mathrm{M}=$ total miles of water mains in the distribution system

$\mathrm{e}=$ error term

The estimates of the coefficient $d_{n}, n=1,2,3,4$ in equation [3] measure the quantity of water that must be put in the system in order to supply the n'th customer with an additional gallon of water. These estimated coefficients were combined with estimates obtained in equation [2] to form estimates of the short-run marginal cost for each customer class.

Recall that we define long-run marginal cost as the sum of short-run marginal cost and the marginal capacity charge. Water utilities would need to construct an additional unit of productive capacity to meet future peak-period demand beyond its existing capacity. And peak demand will most likely be positively related to total demand. Therefore, in this paper we derive estimates of the marginal capacity charge in two steps. The first step entails regressing total fixed cost on peak demand. The next step entails regressing peak demand on total demand. Marginal capacity charge is now defined as the change in fixed cost resulting from an additional unit of peak demand times the change in peak demand for a given change in total demand (i.e., marginal plant charge $\left[\mathrm{MP}_{\mathrm{c}}\right]$ equals $\mathrm{dTFC} / \mathrm{dCP} * \mathrm{dCP} /$ dD).(4) This method is similar to that used to calculate the marginal capacity charge in the electric utility industry (Primeaux and Nelson, 1980, and DiLorenzo and Robinson, 1982).

How to allocate cost among customer classes is a difficult problem to deal with. There are several costallocation methods that are used in the electric utility industry with a relatively high degree of sophistication. Three most frequently discussed are: the coincidentpeak method, the non-coincident peak method, and the average and excess demand method (BonBright, 1961). Theoretically, the appropriate method would employ marginal cost pricing which assigns marginal plant cost in proportion to the contribution of each customer class to the coincident peak. The magnitude of the coincident peak is a measure of how close the peak demand of an individual class of customer coincides with the system peak. In the event that a customer class does not use any service at the time of system peak, that customer class would receive no allocation of fixed cost. To implement this method requires data regarding the contribution of each customer to the utility's coincident peak data which are not available in many cases.

To overcome these data problems in the coincident peak method, Primeaux and Nelson (1980) allocate marginal capacity costs to each customer class by multiplying the marginal plant charge by the total system peak demand, and then distributing this charge to the individual customer classes in proportion to their individual contributions to total demand. It is assumed that this allocation method is equivalent to marginal cost pricing if each customer class's demand at the system peak were similar to each class's annual total demand.

This latter method of allocating marginal capacity cost among customer classes is adopted in this paper. It is expressed as:

$\mathrm{MP}_{\mathrm{c}}^{\mathrm{n}}=\mathrm{SQ}_{\mathrm{n}} \times \mathrm{MP}_{\mathrm{C}} \times \mathrm{CP} \times \mathrm{Q}_{\mathrm{n}}^{-1}$

where

$\mathrm{MP}_{\mathrm{c}}^{\mathrm{n}}=$ marginal plant charge of the n'th customer class $\mathrm{SQ}_{\mathrm{n}}=$ percentage of the n'th customer class's demand to total demand

$\mathrm{Q}_{\mathrm{n}}=$ annual demand of the $\mathrm{n}$ 'th customer class

$\mathrm{CP}=$ annual capacity of the system

The total long-run marginal cost of residential users $\left(\mathrm{LRMC}_{\mathrm{r}}\right)$, commercial users $\left(\mathrm{LRMC}_{\mathrm{c}}\right)$ and industrial users $\left(\mathrm{LRMC}_{\mathrm{i}}\right)$ is now defined as the sum of the shortrun marginal cost and the marginal capacity costs.

$\mathrm{LRMC}_{\mathrm{r}}=\mathrm{SRMC}_{\mathrm{r}}+\mathrm{MP}_{\mathrm{c}}^{\mathrm{n}}$
$\mathrm{LRMC}_{\mathrm{c}}=\mathrm{SRMC}_{\mathrm{c}}+\mathrm{MP}_{\mathrm{c}}^{\mathrm{n}}$
$\mathrm{LRMC}_{\mathrm{i}}=\mathrm{SRMC}_{\mathrm{i}}+\mathrm{MP}_{\mathrm{c}}^{\mathrm{n}}$

\section{Data}

For a full analysis of the existence of price discrimination among customer classes in the water industry, user and system operating data must be available to estimate cost equations and to determine prices. Most of the data used in this paper are collected from the Annual Survey of the American Water Works Association. These data were collected by the Association for both publicly-owned and investor-owned utilities throughout the country for 1976 . The operating data included information on water production and distribution, monthly water rates for four blocks of consumption (3750, 7500, 75,000 and 750,000 gallons, respectively), water revenue by customer class, operating cost and other financial information. Information on the physical elements of each utility such as miles of water mains and capacity were also provided.(5) The following analysis includes only those observations reported by investor-owned utilities that furnished complete data concerning all the relevant variables incorporated in our models. Our sample consists of 29 privately-owned utilities.

\section{Empirical Test of Price Discrimination}

The test for price discrimination involves estimating the marginal cost and the price of service for each user group (commercial, residential and industrial). The extent of the variation in the price-marginal cost ratios 
among the three customer groups signals the existence of price discrimination and thus indicates which customer class received the most favorable rates. The ordinary least squares or total variable cost are presented in Table 1, equation [6]. commercial and industrial sectors are: $.1597, .1805$ and .0186 gallons, respectively. To provide one gallon of water to residential, commercial and industrial users, it is necessary to produce $1.1597,1.1805$ and 1.0186 gallons, respectively. Thus, estimates of the short-run

Table 1

Regression Results: Equations [6] - [9] - Ordinary Least Squares Estimates (Privately-Owned Utilities) ${ }^{\mathrm{a}}$

\begin{tabular}{|c|c|c|c|c|c|c|c|}
\hline & Equation & Intercept & $\mathrm{Q}_{w}$ & $Q_{w}{ }^{2}$ & $\mathrm{CP}$ & $Q_{w} \times C P$ & \\
\hline$[6]$ & $\begin{array}{l}\text { Total } \\
\text { Variable } \\
\text { Cost }\end{array}$ & 180.83 & $\begin{array}{l}0.3143 * \\
(3.38)\end{array}$ & $-0.0430 \times 10^{-4^{* *}}$ & $\begin{array}{l}-0.0425 \\
(-0.68)\end{array}$ & $0.0342 \times 10^{-4^{*}}$ & $\begin{array}{l}\mathrm{R}_{2}=0.972 \\
\mathrm{~F}=214.29\end{array}$ \\
\hline
\end{tabular}

\begin{tabular}{|c|c|c|c|c|c|c|c|c|}
\hline & Equation & Intercept & $Q_{\text {resident121 }}$ & Q industrial & $Q_{\text {commercial }}$ & Q other & $\begin{array}{c}\text { Miles of } \\
\text { Lines } \\
\end{array}$ & \\
\hline [7] & $\begin{array}{l}\text { Distribution } \\
\text { Lineloss }\end{array}$ & 4.7748 & $\begin{array}{l}0.1597 * \\
(7.27)\end{array}$ & $\begin{array}{l}0.0186 \\
(0.23)\end{array}$ & $\begin{array}{l}0.1805 * * \\
(1.86)\end{array}$ & $\begin{array}{l}0.1090 \\
(1.25)\end{array}$ & $\begin{array}{l}0.2829 \\
(1.41)\end{array}$ & $\begin{array}{l}R^{2}=0.993 \\
F=1106.9\end{array}$ \\
\hline
\end{tabular}

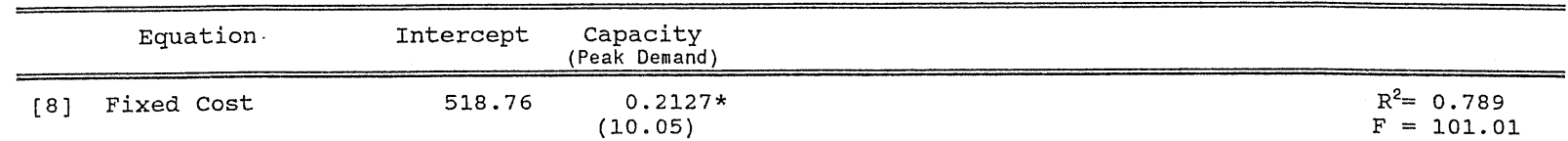

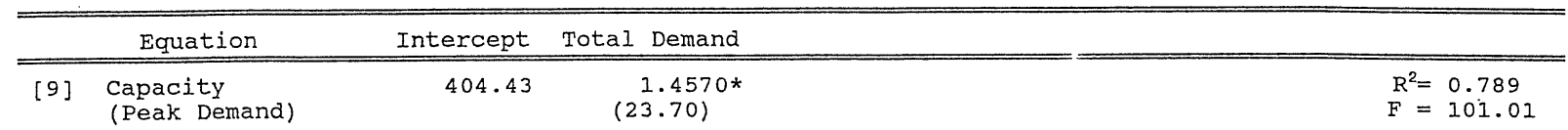

${ }^{a}$ Numbers in parentheses are t-ratios.

*Denotes significance at the 5 percent level or better, one-tailed test.

**Denotes significance at the 10 percent level or better, one-tailed test.

An examination of the individual regression coefficients shows the coefficients of the quantity and quantity-squared variables are statistically significant at the 5 percent and 10 percent level, respectively, in a one-tailed test. Almost 97 percent of the variation in total variable costs can be explained by the variables in the equation; and the regression equation is significant at the 1 percent level.

The short-run marginal cost (SRMC) of providing a unit of water is obtained by the partial derivative of equation (6) with respect to $\mathrm{Q}_{\mathrm{w}}$.

$\mathrm{SRMC}=0.3143-0.0860 \times 10^{-4} \mathrm{Q}_{\mathrm{w}}+0.0342 \times 10^{-4} \mathrm{CP}$

Using [6A], the short-run marginal cost of providing an additional million gallons of water in these systems ranges from $\$ 67.78$ to $\$ 313.04$.

Estimates of distribution line losses incurred in serving the three customer classes are based on a sample of 11 water utilities and are presented in Table 1, equation [7]. All the coefficients have the expected signs. Estimated marginal line losses for the residential, marginal cost for each customer class are $\mathrm{SRMC}_{\mathrm{r}}=$ 1.1597 SRMC; $\mathrm{SRMC}_{\mathrm{c}}=1.1805 \mathrm{SRMC}$ and $\mathrm{SRMC}_{\mathrm{i}}=$ 1.0186 SRMC.

The ordinary least squares estimates of the equations used to obtain the marginal plant charge are given in Table 1 in equations [8] and [9]. The estimated marginal plant charge equals 0.3099. The marginal plant charge is allocated among the three customer classes using equation [4] and added to the short-run marginal cost for each customer class to get the long-run marginal for each class.

We can now determine the extent of price discrimination among customer classes by examining the price-tolong-run marginal cost (P/LRMC) ratios for each customer class. Two measures of price are used. The first is the average revenue $\left(\mathrm{P}_{\mathrm{A}}\right)$ for each customer class. The second is the marginal price $\left(\mathrm{P}_{\mathrm{M}}\right)$ defined here as the difference in the monthly bills between successive consumption blocks (if the consumption level is between blocks), divided by the difference in block consumption levels.(6) If price discrimination exists, we would expect to find significant differences in the (P/LRMC) ratios of 
different customer classes. The price discrimination hypothesis is tested by using long-run marginal costs. The long-run marginal cost is more accurate in practice because firms may not be able to adjust to changes in short-run marginal cost-for example, certain institutional rigidities (e.g., unions) in the use of labor inputs may prevent this. Moreover, some earlier writers (notably, Turvey, 1969) have recommended choosing stable rates, generally based on long-run marginal cost, to avoid the difficulties customers might face in adjusting to price levels that constantly change through time. However, for empirical completeness, we presented the priceshort-run marginal cost (P/SRMC) results.

The results of the F-test are presented in Table 2. The mean ratios of price to long-run marginal cost for the residential, commercial and industrial users are 1.52, 1.16 and 1.12 , respectively using the average revenue measure of price and are 1.28, 1.23 and 1.16, respectively when marginal price is employed. Regardless of the price measure used, the price-marginal cost ratios of the industrial customers are always less than those of the residential and commercial customer classes. The Fstatistic clearly indicates that a statistically significant difference exists between the price-long-run marginal cost ratios of the three customer classes when the average price measure is employed. The difference is significant at the 5 percent level or better in a one-tailed test. The difference is not statistically significant when the marginal price measure is used. In general, privately-owned water utilities practice price discrimination and they have a price structure that burdens the residential customer class and favors the industrial customer group. The average (marginal) price-marginal cost ratio for the industrial customer class is 26 percent ( 8 percent) below that of the residential customer class and 4 percent $(5$ percent) below that of the commercial customer class. The results of the differences between the price marginal cost ratios of three pair-wise comparisons are presented in Table 3, as well as t-statistics.

Table 2

Comparison of Mean Ratios of Price to Marginal Cost (standard deviations in parentheses)

\begin{tabular}{ccccc|}
\hline \hline & & & \\
\hline $\begin{array}{c}\text { Price- } \\
\text { Cost Ratios }\end{array}$ & Residential & Commercial & Industrial & F-statistics \\
\hline $\mathrm{P}_{\mathrm{A}} /$ SRMC & 4.75 & 3.65 & 3.09 & 1.70 \\
& $(2.70)$ & $(2.12)$ & $(2.16)$ & \\
$\mathrm{P}_{\mathrm{W}} /$ SRMC & 4.20 & 3.89 & 2.82 & 0.10 \\
& $(3.04)$ & $(2.32)$ & $(2.02)$ & \\
$\mathrm{P}_{\mathrm{A}} /$ LRMC & 1.52 & 1.16 & 1.12 & $11.59 *$ \\
& $(0.52)$ & $(0.24)$ & $(0.18)$ & \\
$\mathrm{P}_{\mathrm{W}} /$ LRMC & $(1.29$ & 1.23 & 1.16 & 0.83 \\
\hline \hline
\end{tabular}

*Significant at the 5 percent level or better, one-tailed test.
Table 3

Differences Between Mean Ratios of Price to Long-Run Marginal Cost for Privately-Owned Water Utilities

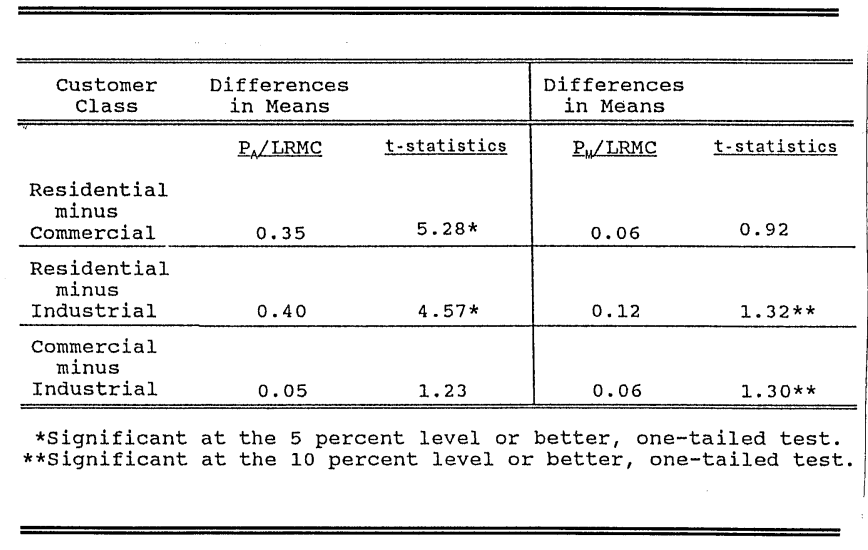

The results suggest that the difference among the average price-marginal cost ratios of the pairs of users-residential and commercial, residential and industrial, and commercial and industrial-are statistically significant at the 5 percent level. For marginal price-marginal cost ratio, the differences between residential and industrial users and between commercial and industrial users are statistically significant at the 10 percent level or better. The evidence suggests rate concessions to the industrial users are statistically significant. The null hypothesis that the true mean ratio for the industrial customer class is greater than unity cannot be rejected at the 1 percent level in a one-tailed test when both average price (t-value 33.17) and marginal price (t-value 24.76) are employed in the pricemarginal cost ratios. Thus, the firms in the sample do not practice internal cross-subsidization.

The results of the pair-wise comparisons for deviations in price-marginal cost ratios across customer classes on a utility-by-utility basis are presented in Table 4. The evidence further indicates that the industrial customer class is the most favored group. Economic theory would relate this result to demand conditions applicable to each group of users. Do regulators set water rates based on different price elasticities of demand of the several customer classes? That is, do regulators set Ramsey prices?

\section{Ramsey Pricing in the Water Industry}

In its simplest form, the Ramsey pricing rule insures that welfare will be maximized if the deviation from marginal cost is inversely related to the customer class' elasticity of demand. We would expect that Ramsey prices for the customer class with relatively inelastic demands would deviate furthest from marginal cost, while Ramsey prices for the customer class with relatively elastic demands would deviate least from marginal 
Table 4

Comparison of the Differences in Price-Marginal Cost Ratios

Across Customer Classes for Individual Utilities

\begin{tabular}{|c|c|c|c|c|}
\hline $\begin{array}{l}\text { Customer } \\
\text { Class }\end{array}$ & $\begin{array}{c}\text { Average Price- } \\
\text { Marginal-Cost Ratio } \\
\end{array}$ & $\begin{array}{l}(\%) \text { Utilities } \\
\text { in Sample } \\
\end{array}$ & $\begin{array}{c}\text { Marginal Price- } \\
\text { Marginal-Cost Ratio } \\
\end{array}$ & $\begin{array}{l}\text { (\%) Utilities } \\
\text { in Sample }\end{array}$ \\
\hline Residential & $P_{\underline{A}}^{r} /$ LRMC $_{r}>1$ & $93 \%$ & $\mathrm{P}_{H}^{r} / L_{2} \mathrm{RMC}_{r}>1$ & $83 \%$ \\
\hline Commercial & $P_{A}^{c} /$ LRMC $_{c}>1$ & $79 \%$ & $P_{W}^{c} /$ LRMC $_{c}>1$ & $86 \%$ \\
\hline Industrial & $\mathrm{P}_{A}^{1} /$ LRMC $_{1}>1$ & $83 \%$ & $\mathrm{P}_{M}^{1} / \operatorname{LRMC}_{1}>1$ & $76 \%$ \\
\hline $\begin{array}{l}\text { Residential } \\
\text { minus } \\
\text { commercial }\end{array}$ & $P_{A}^{r} / L_{R M C}-P_{A}^{c} / L_{R M C}>0$ & $97 \%$ & $P_{W}^{r} / L_{R M C}-P_{W}^{c} / L_{R M C}>0$ & $90 \%$ \\
\hline $\begin{array}{l}\text { Residential } \\
\text { minus } \\
\text { Industrial }\end{array}$ & $\mathrm{P}_{A}^{r} /$ LRMC $_{r}-\mathrm{P}_{A}^{1} /$ LRMC $_{1}>0$ & $69 \%$ & $\mathrm{P}_{W}^{r} / \operatorname{LRMC}_{r}-\mathrm{P}_{W}^{1} / \operatorname{LRMC}_{1}>0$ & $62 \%$ \\
\hline $\begin{array}{l}\text { Commercial } \\
\text { minus } \\
\text { Industrial }\end{array}$ & $\mathrm{P}_{A}^{c} /$ LRMC $_{c}-\mathrm{P}_{A}^{1} /$ LRMC $_{1}>0$ & $41 \%$ & $\mathrm{P}_{\mathrm{H}}^{\mathrm{c}} / \mathrm{LRMC}_{\mathrm{c}}-\mathrm{P}_{\mathrm{W}}^{1} /$ LRMC $_{1}>0$ & $38 \%$ \\
\hline
\end{tabular}

costs. Ramsey prices are usually presented under the assumption of zero cross-price elasticities of demand. Therefore, the welfare optimal prices, subject to the constraint that firms earn normal profit or some predetermined level of profits, must satisfy

$\frac{P_{i}-M_{C}}{P_{i}} \cdot E_{i}=\lambda$

where

$E_{i}=$ the own price elasticity of demand for customer class $\mathrm{i}$

$\mathrm{MC}_{1}=$ long-run marginal cost of serving customer $\mathrm{i}$

$P_{i}=$ price of service to customer $i$

$\frac{\lambda}{1+\lambda}=$ Ramsey number

Prices satisfying this condition [13] are referred to as Ramsey prices while the factor of proportionality $\lambda / 1+$ $\lambda$, is called the Ramsey number.

If water utility regulators set Ramsey prices, the Ramsey number will be the same for all customer classes served; because the Ramsey rule, according to [10], requires that customer classes with different demand elasticities pay rates that exceed marginal cost by the same ratio as the inverse ratio of differences in demand elasticity.

To test the existence of Ramsey pricing in this industry requires, among other things, the estimates of long-run demand elasticities. The next step is to obtain estimates of the price elasticity of demand for water for different classes of users-residential, commercial, industrial. We obtained estimates of the average price elasticities and the marginal price elasticities for residential commercial and industrial users from an earlier study by Williams and Suh (1986).(7) The estimates of the average price elasticity are $-.4835,-.3602$ and -.7352 . for residential, commercial and industrial users, respectively. While the marginal price elasticity estimates are $.3602,-.1406$ and -.4736 for the residential, commercial and industrial classes, respectively. The values for the industrial class are higher than those reported for the residential and commercial classes. This suggests that the industrial customer class is more responsive to price changes than the other two classes. This finding is reasonable when we consider that industrial customers are more likely to use alternative sources of supply or recycle water in the production process in the face of significant price increases (Williams and Suh, 1986).

\section{Test of Ramsey Pricing}

Table 5 reports the estimates of the mean average (marginal price-marginal cost) ratios, Ramsey numbers and estimates of the elasticity of demand for each customer class. Generally, we observe that the estimated price-long-run marginal cost ratios across customer classes vary inversely with the estimates of the long-run price elasticities of demand-a pattern that will be consistent with the Ramsey pricing rule. In practice, to invoke the Ramsey pricing rule, the Ramsey numbers which represent the percentage deviations of price from marginal cost weighted by the price elasticity of demand must be the same for all customer classes.

We used the F-test to determine whether state regulators adopted the Ramsey pricing rule in setting water utility rates. The results of the F-statistics and the associated level of significance in parentheses are given in Table 6.

F-statistics in [1A] and [1B] indicate that the hypothesis of equality of Ramsey numbers for all customer classes may be rejected at the 1 percent level. The 
Table 5

Data For Evaluating Pricing

Sample Means of Price-Marginal Cost Ratios, Ramsey Numbers and Estimates of Price Elasticities of Demand

\begin{tabular}{|c|c|c|c|}
\hline Estimates & Residential & $\begin{array}{l}\text { Customer } \\
\text { Class } \\
\text { Commercial }\end{array}$ & Industrial \\
\hline $\begin{array}{l}\text { Average Revenue } \\
\text { Price Elasticity }\end{array}$ & $\begin{array}{l}-0.4835 \\
(-5.07)\end{array}$ & $\begin{array}{l}-0.3602 \\
(-5.55)\end{array}$ & $\begin{array}{l}-0.7352 \\
(-2.52)\end{array}$ \\
\hline $\begin{array}{l}\text { Average Revenue } \\
\text { Price-Long-Run } \\
\text { Marginal Cost }\end{array}$ & $\begin{array}{c}1.52 \\
{[0.52]}\end{array}$ & $\begin{array}{c}1.16 \\
{[0.24]}\end{array}$ & $\begin{array}{c}1.12 \\
{[0.18]}\end{array}$ \\
\hline Ramsey Number & $\begin{array}{l}-0.1317 \\
{[0.1107]}\end{array}$ & $\begin{array}{l}-0.0383 \\
(0.0589)\end{array}$ & $\begin{array}{l}-0.0585 \\
{[0.1193]}\end{array}$ \\
\hline $\begin{array}{l}\text { Marginal Price } \\
\text { Elasticity }\end{array}$ & $\begin{array}{l}-0.3602 \\
(5.55)\end{array}$ & $\begin{array}{l}-0.1406 \\
(-1.29)\end{array}$ & $\begin{array}{l}-0.4376 \\
(-1.83)\end{array}$ \\
\hline $\begin{array}{l}\text { Marginal } \\
\text { Price-Long-Run } \\
\text { Marginal Cost }\end{array}$ & $\begin{array}{l}1.28 \\
{[0.47]}\end{array}$ & $\begin{array}{c}1.23 \\
{[0.21]}\end{array}$ & $\begin{array}{c}1.16 \\
{[0.25]}\end{array}$ \\
\hline Ramsey Number & $\begin{array}{l}-0.0485 \\
{[0.1081]}\end{array}$ & $\begin{array}{l}-0.0179 \\
{[0.0318]}\end{array}$ & $\begin{array}{l}-0.0493 \\
{[0.0869]}\end{array}$ \\
\hline
\end{tabular}

equality of the Ramsey numbers for the customer class pairings-residential and commercial, and commercial and industrial may similarly be rejected at the 1 percent level, but we cannot reject the equality of the Ramsey number for the residential and industrial customer pairings. The F-statistic is 0.6704 .

When adjustments are made in the price-marginal cost ratios for any two customer groups, to reflect differences in their respective price elasticities, the original disparity between the pairwise comparisons of these ratios should be greatly reduced. But the results indicate that this is not the case. For example, the ratio of the residential to industrial, residential to commercial and the commercial to industrial average price-marginal cost ratios are 1.357, 1.666 and 1.036 , respectively; and the associated ratios of the Ramsey numbers are 2.251, 7.614 and 0.655 . The initial disparities have either enlarged or fallen sharply below unity. This suggests that the prices are not set to reflect differences in the elasticity of demand in accordance with the Ramsey rule.

\section{Summary and Conclusions}

This paper is concerned with the extent of price discrimination among customer classes for privatelyowned water utilities that are regulated by state commissions. The test of price discrimination requires the specification and estimation of long-run marginal cost functions for each class of customer and prices of service. This procedure yields the price-long-run marginal cost ratios for each customer class required to test for price discrimination. Our results indicate that the rate structure of privately-owned water utilities burden the residential and commercial customer classes and favor the industrial customer class.

We examine whether the rates afforded the respective customer classes are set in accordance with variations in the elasticity of demand of the respective customer classes. In so doing, we proceed to test the existence of

Table 6

F-Tests for Ramsey Pricing

\begin{tabular}{ccccc}
\hline \hline \multicolumn{1}{c}{$\begin{array}{c}\text { Test } \\
\text { Statistic }\end{array}$} & $\begin{array}{c}\text { Residential } \\
\text { Commercial } \\
\text { Industrial }\end{array}$ & $\begin{array}{c}\text { Residential } \\
\text { Commercial }\end{array}$ & $\begin{array}{c}\text { Residential } \\
\text { Industrial }\end{array}$ & $\begin{array}{c}\text { Commercial } \\
\text { Industrial }\end{array}$ \\
\hline \hline \multirow{2}{*}{ IA } & 7.012 & 16.086 & 0.670 & 5.862 \\
& $(0.0015)$ & $(0.0002)$ & $(0.4164)$ & $(0.0187)$ \\
1B & 1.382 & 2.149 & 3.347 & 0.976 \\
& $(0.2566)$ & $(0.1482)$ & $(0.0726)$ & $(0.0009)$ \\
\hline \hline
\end{tabular}

aThe numbers in parentheses denote level of significance.

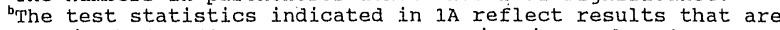
obtained when the average revenue price is used. Those indicated in $1 \mathrm{~B}$ reflect results for marginal price.

Ramsey pricing. Demand equations are estimated by class of customer. Residential and commercial demand are more sensitive to price changes than industrial demand. Our results indicate that regulators do not set Ramsey prices, suggesting that other factors are significant in determining rates for water customers by class.

\section{Suggestions For Future Research}

These results are of independent interest in that they suggest that demand elasticity estimates by customer class have little relevance in private water utility pricing schemes. It would seem that the most useful direction for future research is to consider whether private water utility regulators set prices in a manner that exclusively serve the private interest of those they regulate.

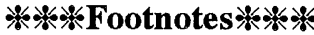

1. The existing theories do not explain how regulation which enforces cross-subsidization extraction of higher profits from a stronger market segment and subsidize lower prices in a weaker market segment produces market distortions and sub-optimum welfare effects. See Posner (1971) for a lucid discussion on this aspect of regulation.

2. The theory of Ramsey pricing has been extended and examined by Baumol and Bradford (1970), Braeutigam (1979) and Damus (1984). Empirical tests of the existence of Ramsey pricing have been conducted for the electric industry, Nelson (1980).

3. Other variables besides output and capacity were 
explored. Factors that affect service quality and service-mix of water utilities would explain differences in network costs. Service attributes such as total metered customers per miles of lines and population density were included in a number of different cost function specifications, but the final specification given in equation [1] proved superior. The specification is similar to the one employed by Primeaux and Nelson (1980), Hollas (1980) in the electric utility industry and Bruggink (1982) in the water utility industry.

4. The marginal plant charge is summarized as follows: $\mathrm{TFC}=\mathrm{t}_{\mathrm{o}}+\mathrm{t}_{1} \mathrm{CP}+\mathrm{U}_{1}$ and $\mathrm{CP}=\mathrm{r}_{\mathrm{o}}+\mathrm{r}_{1} \mathrm{D}+\mathrm{U}_{2}$ thus $\mathrm{MP}_{\mathrm{c}}=\mathrm{t}_{1} \mathrm{r}_{1}$; where $\mathrm{TFC}=$ total fixed cost (i.e., interest on long-term debt, amortization, depreciation, income and property taxes and profits); $\mathrm{CP}=$ annual capacity of water system (surrogate for peak demand): $\mathrm{D}=$ total annual water demanded (in million gallons); $t_{1} r_{1}=$ change in fixed cost arising from serving an additional unit of demand times change in peak demand given a change in total demand; and $\mathrm{U}_{1}$ and $\mathrm{U}_{2}$ are random errors, respectively.

5. For a limited set of utilities where the capacity information was reported incorrectly, we approximated the capacity measure to be one hundred and fifty percent of the total water distributed. This general pattern was reflected between the capacity measure and the total water distributed for a large percentage of the utilities in the sample.

6. This is one of the several measures of marginal price that was used by Houthakker et al. (1974) in their electric utility study. Six utilities in our privately-owned sample reported average revenue price information for industrial users that was unreasonable. In those individual cases, we used the calculated price per one thousand gallons that was charged the commercial users.

7. The marginal price is defined as the price of water between successive consumption blocks. (See Williams and Suh, 1986; Table 1).

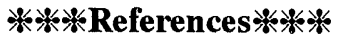

1. Baumol, William J. and David F. Bradford, "Optimal Departures from Marginal Cost Pricing," American Economic Review, Vol. 60, pp. 265-283, 1970.

2. BonBright, James C. Principles of Public Utility Rates. Columbia University Press, New York, 1961.

3. Bruggink, Thomas II., "Third-Degree Price Discrimination and Regulation in the Municipal Water Industry," Land Economics, Vol. 58, pp. 86-95, 1982.

4. Braentigam, Ronald B., "Optimal Pricing with Intermodal Competition," American Economic Review, Vol. 69, pp. 38-49, 1979.

5. Damus, Sylvester, "Two-Part Tariff and Optimum Taxation: The CaSe of Railway Rates," American
Economic Review, Vol. 71, pp. 65-79, 1981.

6. DeAlessi, Louis, "An Economic Analysis of Government Ownership and Regulation," Public Choice, Vol. 19, pp. 1-41, 1974.

7. DiLorenzo, Thomas J. and Ralph Robinson, "Managerial Objectives Subject to Political Market Constraints: Electric Utilities in the U.S.," Quarterly Review of Economics and Business, Vol. 22, pp. 113$125,1982$.

8. Farris, Martin T. and Roy J. Sampson, Public Utilities: Regulation, Management and Ownership. Houghton Mufflin Co. Boston, 1973.

9. Hanke, Steve H., "Pricing Urban Water" Chapter 12 in Public Prices for Public Products, ed. Selma Muskin, Washington: The Urban Institute, 1976.

10. Hanke, Steve H. and Robert K. Davis, "Potential for Marginal Cost Pricing in Water Resource Management," Water Resources Research, Vol. 9, No. 4, pp. 808-825, 1973.

11. Hanke, Steve H., "Crisis Ridden Systems Should Go Private," Wall Street Journal, September 3, p. 18, 1981.

12. Hollas, Daniel and Thomas Friedland, "Price Discrimination in Municipal Electric Industry," Research in Law and Economics, 1980.

13. Hotelling, H., "The Economics of Exhaustible Resources," Journal of Political Economy, Vol. 39, pp. 137-175, 1931.

14. Houthakker, Hendrik W., Philip K. Verleger, Jr. and D. P. Sheehan, "Dynamic Demand Analysis for Gasoline and Residential Electricity," American Journal of Agricultural Economics, Vol., pp. 412-418, 1974.

15. Keeler, Theodore E., "Airline Regulation and Market Performance," Bell Journal Economic and Management Science, Vol. 3, pp. 399-424, 1972.

16. Kitchen, Harry M., "A Statistical Estimation of an Operating Cost Function for Municipal Water Provision," Urban Analysis, Vol. 4, pp. 119-113, 1977.

17. Leland, Hayne and Robert A. Meyer, "The Effectiveness of Price Regulation," Review of Economics and Statistics, Vol., pp. 555-566, 1980.

18. Meyer, Robert A., "Publicly Owned Versus Privately Owned Utilities: A Policy Choice," The Review of Economics and Statistics, Vol. 57, pp. 391-399, 1975.

19. Nelson, Randy A., "An Empirical Test of the Ramsey Theory and Stigler-Peltzman Theory of Public Utility Pricing," Economic Inquiry, Vol. 20, pp. 277-290, 1982.

20. Peltzman, Sam, "Pricing in Public and Private Enterprises: Electric Utilities in the United States," Journal of Law and Economics, Vol., pp. 109-147, 1971.

21. Posner, Richard A., "Taxation by Regulation," The Bell Journal of Economics, Vol., pp. 22-50, 1971.

22. Primeaux, Walter J., Jr. and Randy A. Nelson, "An Examination of Price Discrimination and Internal Subsidization by Electric Utilities," Southern Eco- 
nomic Journal, Vol. 27, pp. 84-99, 1980.

23. Stigler, George and Thomas Friedland, "What Can Regulators Regulate? The Case of Electricity," Journal of Law and Economics, Vol., pp. 1-16, 1962.

24. Stigler, George, "The Theory of Economic Regulation," Bell Journal of Economics, Vol., pp. 3-21, 1971.

25. Turvey, Ralph, "Marginal Cost," Economic Journal, Vol. 79, pp. 282-299, 1969.

26. U.S. Department of Commerce, City and County Data Book, Washington, D.C., U.S. Government Printing Office, 1972.

27. Williams, Martin and Byung Suh, "The Demand for Urban Water by Customer Class," Applied Economics, Vol. 18, pp. 1275-1289, 1986. 